\title{
Timing of Late Quaternary glaciation along the southwestern slopes of the Qilian Shan, Tibet
}

LEWIS A. OWEN, JOEL Q. SPENCER, MA HAIZHOU, PATRICK L. BARNARD, EDWARD DERBYSHIRE, ROBERT C. FINKEL, MARC W. CAFFEE AND ZENG YONG NIAN

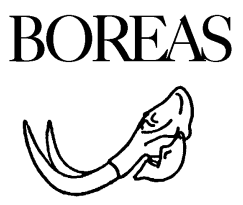

\begin{abstract}
Owen, L. A., Spencer, J. Q., Haizhou, M., Barnard, P. L., Derbyshire, E., Finkel, R. C., Caffee, M. W. \& Nian, Z. Y. 2003 (June): Timing of Late Quaternary glaciation along the southwestern slopes of the Qilian Shan, Tibet. Boreas, Vol. 32, pp. 281-291. Oslo. ISSN 0300-9483.

Moraines along the southwestern slopes of the Qilian Shan were dated using cosmogenic radionuclide (CRN) surface exposure techniques to help define the timing of glaciation in northernmost Tibet. The CRN data show glaciers extending 5-10 km beyond their present positions during the global Last Glacial Maximum (LGM) and probably maintained at their maximum extent until the Lateglacial. These data help support the view that glaciers throughout Tibet and the Himalaya were maintained at or near their maximum LGM extent until the Lateglacial. An optically stimulated luminescence date of $11.8 \pm 1.0 \mathrm{ka}$ on silt that caps a latero-frontal moraine shows that glaciers had retreated significantly by the end of the Pleistocene and that loess was beginning to form in this region in response to the changing climate during and after the Younger Dryas Stade.
\end{abstract}

Lewis A. Owen (e-mail: lewis.owen@ucr.edu), Patrick L. Barnard, Joel Q. Spencer, Department of Earth Science, University of California, Riverside, CA 92521, USA; Ma Haizhou, Zeng Yong Nian, Institute of Saline Lakes, Chinese Academy of Sciences, Xining, Qinghai, P.R. China; Edward Derbyshire, Centre for Quaternary Research, Department of Geography, Royal Holloway, University of London, Egham, Surrey YW20 OEX, UK; Robert C. Finkel, Center for Accelerator Mass Spectrometry, Lawrence Livermore National Laboratory, Livermore, CA 94550, USA; Marc W. Caffee, Department of Physics/PRIME Laboratory, Purdue University, West Lafayette, IN 47907, USA; received 22nd April 2002, accepted 13th November 2002.

The extent and timing of Late Quaternary glaciation throughout Tibet has been greatly debated during the last few decades (Derbyshire et al. 1991; Rutter 1995; Lehmkuhl et al. 1998). This is partly because of the inaccessibility of the region, but also because of the misinterpretation of glacial and non-glacial landforms and sediments that has resulted in different reconstructions of the extent of former glaciers. The contention is further exacerbated by the lack of numerical dating to define the ages of landforms and to make regional correlations. The lack of numerical dating is most apparent for the Pleistocene, because organic matter needed for standard radiocarbon dating is generally preserved only in Holocene sediments in Tibet (Lehmkuhl 1997). Where numerical dating has been undertaken, there has been little attempt to test the chronologies by applying new methodologies and newly developing dating techniques.

The study of the Quaternary glaciation of Tibet is important for modeling the effects of environmental changes on the regional climate and hydrology of the Tibetan Plateau (Hahn \& Suhukla 1976; Dey \& Bhanu Khumar 1982; Dickson 1984; Bush 2000). Yet, despite this, studies designed to reassess the glacial geologic data and to refine chronologies are rare. The Lenglong Ling Mountains in the southwestern Qilian Shan (Shan = Mountains; Fig. 1) is one of the few areas where numerical dating has been undertaken to establish a set of ages to underpin glacial chronologies (Li \&
Li 1991; Shi 1992; Guo \& Chen 1994; Zhou et al. 2002). This area is frequently referenced, having been used to define the timing of glacial events in other parts of Tibet (Li \& Li 1991; Rose et al. 1998; Zhou et al. 2002) using morphostratigraphy and relative weathering techniques. To test and refine the chronologies in this region we have re-assessed the established glacial chronologies and applied cosmogenic radionuclide (CRN) surface exposure and optically stimulated luminescence (OSL) dating to define the ages of moraines.

\section{Methods \\ Field methods and sampling for numerical dating}

Sites appropriate for CRN and OSL dating were identified in the Laolongwan and Gangshiga Valleys with the aid of maps and descriptions from Rose et al. (1998). We also examined the Laotugou valley and produced a reconnaissance map using standard field mapping and morphostratigraphic techniques. Several sets of moraines were differentiated within each valley (Fig. 2).

Rock samples were collected for CRN dating from the surfaces of quartz-rich boulders along moraine crests at locations where there was no apparent evidence of exhumation or slope instability (Fig. 3). Approxi- 


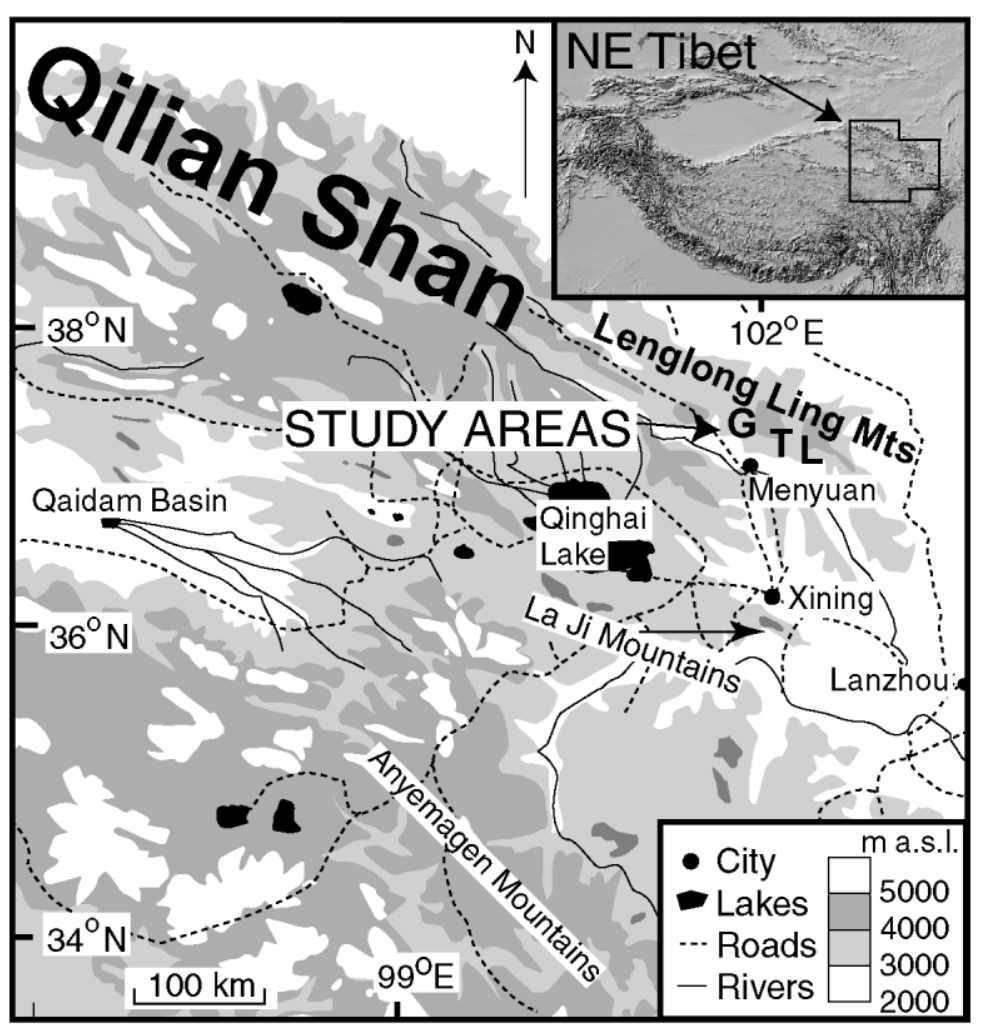

Fig. 1. Location of study area ( $\mathrm{L}=$ Laolongwan valley; $\mathrm{T}=$ Laotugou valley; $\mathrm{G}=$ Gangshiga valley).
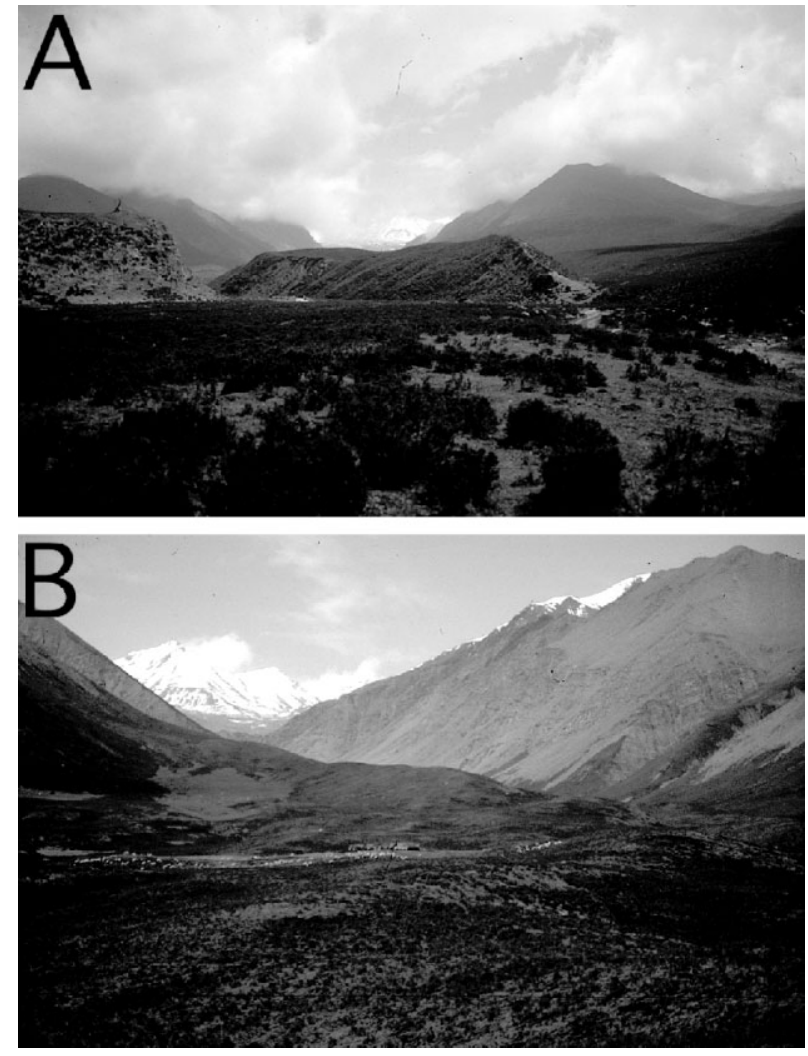

Fig. 2. Views of typical moraine morphologies within the Gangshiga Valley in the Qilian Shan. A. Eroded latero-frontal moraine complex. B. Lateral moraine. mately $1 \mathrm{~kg}$ of rock was collected by chiseling off a $1-$ $2 \mathrm{~cm}$ thick layer of rock from a horizontal upper surface of the boulder. The area that was sampled was generally large $\left(>2500 \mathrm{~cm}^{3}\right)$ and areas showing signs of weathering, for example having weathering pits and depressions, were avoided. This helped to ensure that the samples had representative CRN concentration. Where possible, several boulders were sampled from each moraine ridge to provide a check on the reproducibility of the dating and to check for the possibility of inheritance of CRNs. Photographs and full notes were taken to record the boulder relief (ratio of height to maximum visible horizontal axis), degree of weathering and the site conditions for each boulder (Table 1). The inclination from the boulder site to the top of the surrounding mountain ridges and peaks was measured to determine the topographic shielding.

A sediment sample was collected for OSL dating from a naturally exposed pebbly silt deposit that capped a latero-frontal moraine in the Laotugou valley (Fig. 4). The OSL sample was obtained by hammering an opaque plastic tube into the sediment section. Once removed, the tube was sealed in plastic and stored in a light-tight bag. A subsample was collected to provide material to cross-check OSL sample moisture content and for neutron activation analysis (NAA). The site conditions were recorded and graphic sedimentary logs were constructed. 


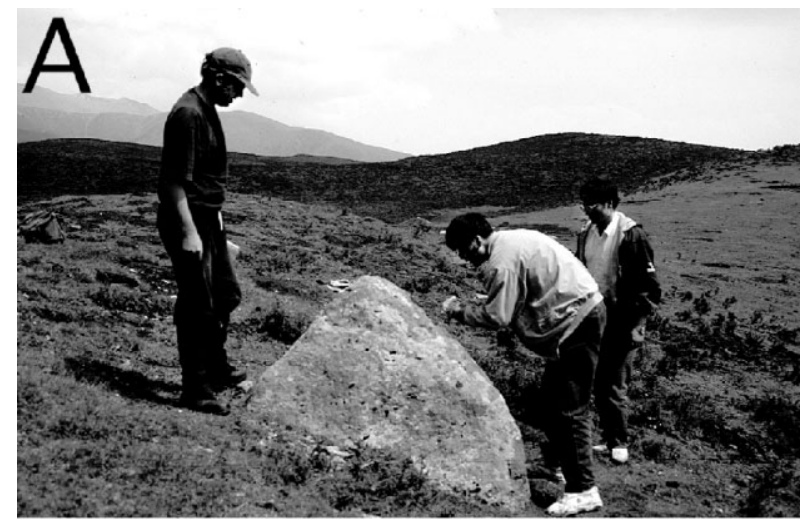

\section{B}
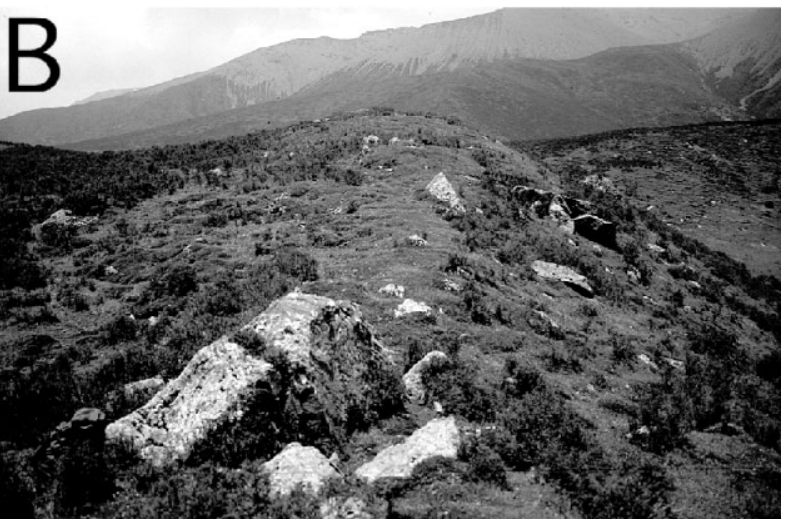

Fig. 3. Typical boulders sampled for CRN dating. A. Boulder slightly offset from the crest of a latero-frontal moraine in the Gangshiga valley. This boulder may have toppled to this position some time after its deposition. Given its large size and present stable position, however, it was considered a candidate for sampling because it would likely have toppled to the position very shortly after deposition. B. A boulder on the crest of a lateral moraine in the Laolongwan Valley. This boulder has a moderate boulder relief and is buried deeply enough to be considered stable; it is therefore an example of a good candidate for $\mathrm{CRN}$ dating.

\section{CRN dating}

For CRN dating, the samples were crushed and sieved. Quartz was separated from the $250-500 \mu \mathrm{m}$ size fraction using the method of Kohl \& Nishiizumi (1992). After the addition of Be carrier and, where necessary, $\mathrm{Al}$ carrier, $\mathrm{Be}$ and $\mathrm{Al}$ were separated and purified by ion exchange chromatography and precipitation at $\mathrm{pH}>7$. The hydroxides were oxidized by ignition in quartz crucibles. $\mathrm{BeO}$ was then mixed with $\mathrm{Nb}$ metal and $\mathrm{Al}_{2} \mathrm{O}_{3}$ with $\mathrm{Ag}$ metal prior to determination of the ${ }^{10} \mathrm{Be} /{ }^{9} \mathrm{Be}$ and ${ }^{26} \mathrm{Al} /{ }^{27} \mathrm{Al}$ ratios by accelerator mass spectrometry at the Center for Accelerator Mass Spectrometry in the Lawrence Livermore National Laboratory. Isotope ratios were compared to ICN ${ }^{10} \mathrm{Be}$ and NIST ${ }^{26} \mathrm{Al}$ standards prepared by $\mathrm{K}$. Nishiizumi (pers. comm. 1995). Stable aluminum concentrations were determined by ICP-ES on aliquots of the dissolved quartz.

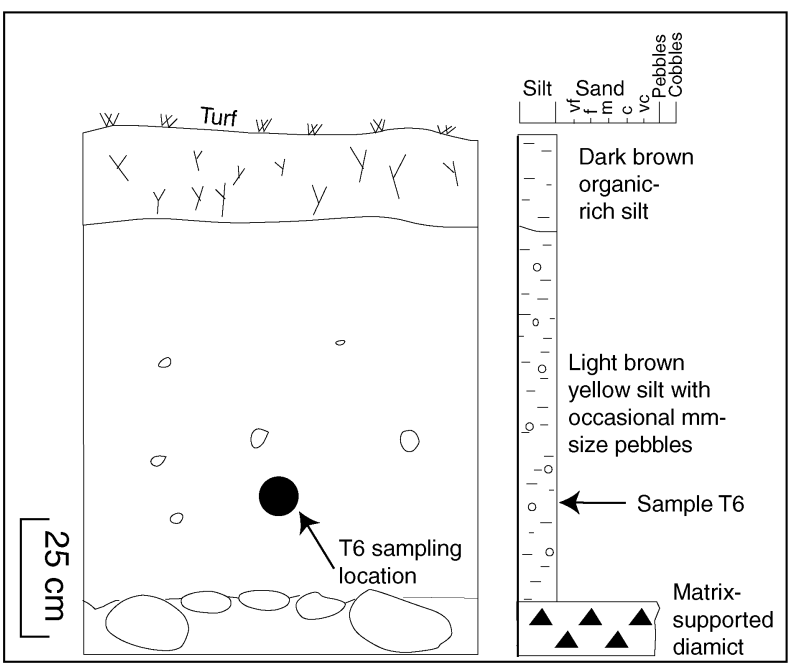

Fig. 4. Field sketch and graphic sedimentary log showing the OSL sampling site. The location is shown in Fig. 8.

The measured isotope ratios were converted to radionuclide concentrations in quartz using the total $\mathrm{Be}$ and $\mathrm{Al}$ in the samples and the sample weights. Radionuclide concentrations were then converted to zero-erosion exposure ages using a sea level high latitude (SLHL) ${ }^{10} \mathrm{Be}$ production rate of $5.2 \mathrm{at} / \mathrm{g}-$ quartz/y and a ${ }^{26} \mathrm{Al} /{ }^{10} \mathrm{Be}$ production ratio of 6.0 (Nishiizummi et al. 1989). The Be production rate used is based on a number of independent measurements, as discussed by Owen et al. (2001, 2002a). Production rates were scaled to the latitude and elevation of the Qilian Shan sampling sites using the star scaling factors of Lal \& Peters (1967) and Lal (1991) and an assumed 3\% SLHL muon contribution, and were further corrected for changes in the geomagnetic field over time. Details of the calculation are given in Owen et al. (2001, 2002a).

\section{OSL dating}

Preparation and measurement procedures were carried out under laboratory safelight conditions to avoid bleaching the luminescence. About $2-3 \mathrm{~cm}$ of sediment, which may have been exposed to daylight during sampling, was removed from the ends of the tube before the sample was carefully extracted. An estimate of the in situ water content (mass of moisture/dry mass; Aitken 1998) was obtained by drying in a $50^{\circ} \mathrm{C}$ oven until the weight stabilized; this measurement was also made on the subsample. Quartz grains (90-125 $\mu \mathrm{m}$ diameter) were then extracted from the sediment remaining in the tube using the following methods: dry and wet sieving, removal of carbonates with $\mathrm{HCl}$, removal of organic matter with $\mathrm{H}_{2} \mathrm{O}_{2}$, and separation of quartz and plagioclase minerals from heavy $\left(>2.74 \mathrm{~g} \cdot \mathrm{cm}^{-3}\right)$ and lighter $\left(<2.62 \mathrm{~g} \cdot \mathrm{cm}^{-3}\right)$ minerals 


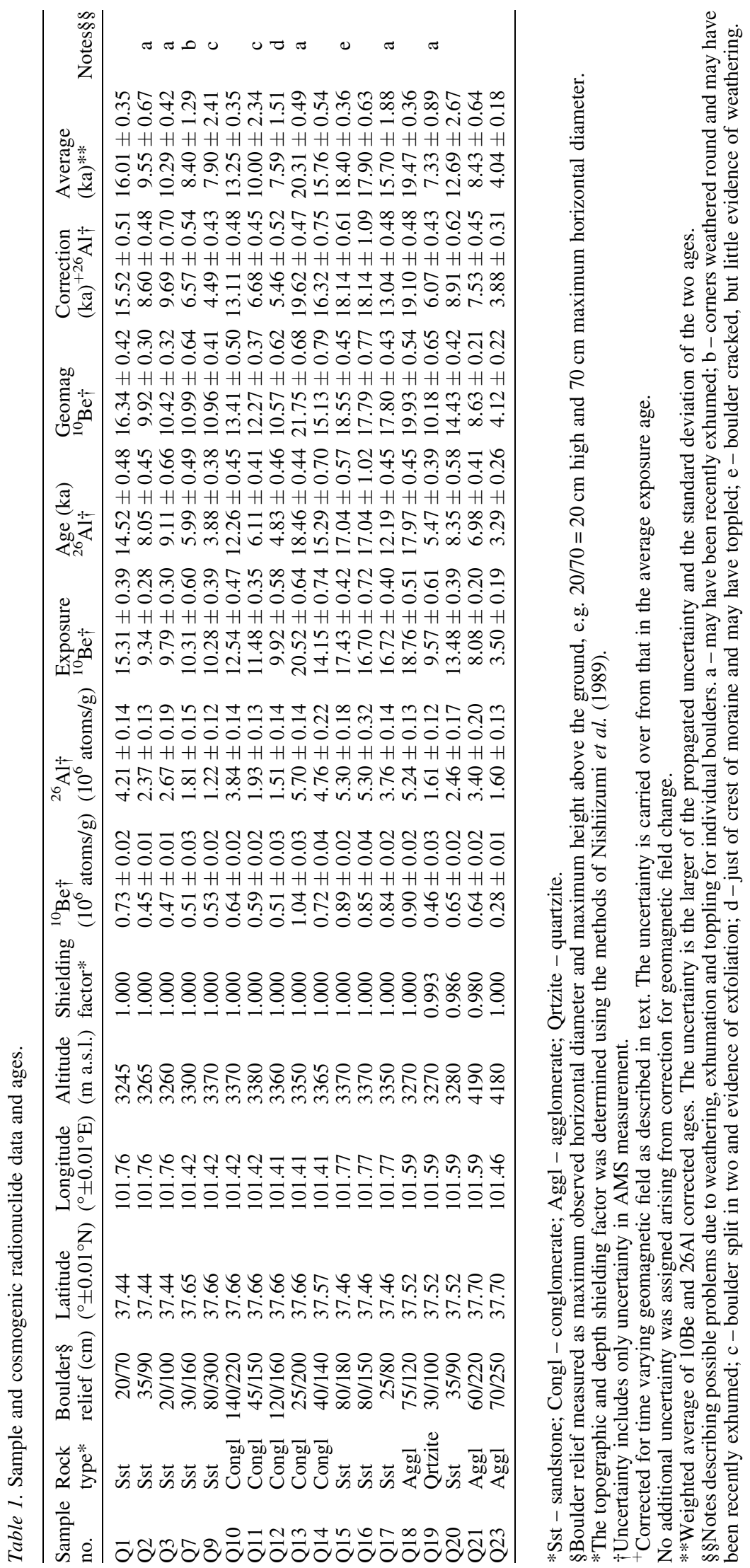


Table 2. Summary of OSL dating results from $90-125 \mu \mathrm{m}$ quartz extracted from sediment sample $\mathrm{T} 6\left(37^{\circ} 31.24^{\prime} \mathrm{E}, 101^{\circ} 35.40^{\prime} \mathrm{N}\right)$ : 1 location details, radionuclide concentrations, moisture content, total dose-rate dosimetry, $\mathrm{D}_{\mathrm{e}}$ estimate and optical age.

\begin{tabular}{llllllllll}
\hline $\begin{array}{l}\text { Altitude } \\
(\mathrm{m} \text { a.s.l })\end{array}$ & $\begin{array}{l}\text { Depth } \\
(\mathrm{cm})\end{array}$ & $\begin{array}{l}\mathrm{U}^{\mathrm{a}} \\
(\mathrm{ppm})\end{array}$ & $\begin{array}{l}\mathrm{Th}^{\mathrm{a}} \\
(\mathrm{ppm})\end{array}$ & $\begin{array}{l}\mathrm{K}^{\mathrm{a}} \\
(\%)\end{array}$ & $\begin{array}{l}\mathrm{Rb}^{\mathrm{a}} \\
(\mathrm{ppm})\end{array}$ & $\begin{array}{l}\mathrm{W}_{\text {in-situ }}{ }^{\mathrm{b}} \\
(\%)\end{array}$ & $\begin{array}{l}\text { Cosmic dose }^{\mathrm{c}} \\
\left(\mathrm{mGya}^{-1}\right)\end{array}$ & $\begin{array}{l}\text { Dose-rate }^{\mathrm{d}} \\
\left(\mathrm{mGya}^{-1}\right)\end{array}$ & $\begin{array}{l}\mathrm{Mean} \mathrm{De}_{\mathrm{e}}{ }^{\mathrm{e}} \\
(\mathrm{Gy})\end{array}$ \\
\hline 3260 & 55 & 2.55 & 13.3 & 1.86 & 85.8 & 2.7 & 0.313 & $\begin{array}{l}\text { Age } \\
(\mathrm{ka})\end{array}$ \\
\hline
\end{tabular}

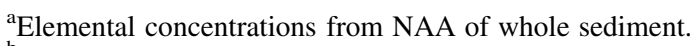

${ }^{\mathrm{b}}$ Estimated fractional water content from whole sediment (Aitken 1998). Uncertainty taken as $\pm 5 \%$.

${ }^{\mathrm{c}}$ Estimated contribution to dose-rate from cosmic rays. Uncertainty taken as $\pm 10 \%$.

dTotal dose-rate from beta, gamma and cosmic components. Beta attenuation factors for U, Th and K compositions calculated using Grün's (1991) 'Age' program incorporating grain size factors from Mejdahl (1979). Beta attenuation factor for Rb arbitrarily taken as 0.75 (cf. Adamiec \& Aitken 1998). Factors utilized to convert elemental concentrations to beta and gamma dose-rates from Adamiec \& Aitken (1998) and beta and gamma components attenuated for moisture content.

${ }^{\mathrm{e}}$ Mean $\mathrm{D}_{\mathrm{e}}$. Errors are 1-sigma standard errors (i.e., $\left.\sigma_{\mathrm{n}-1} / \mathrm{n}^{1 / 2}\right)$ incorporating error from beta source $(\sim \pm 5 \%)$.

by centrifuging in sodium polytungstate solutions of different densities and finally dissolving plagioclase with a $49 \%$ HF etch for $1 \mathrm{~h}$. The quartz grains were mounted on stainless steel discs $(\sim 10 \mathrm{~mm}$ in diameter and thickness of $\sim 0.25 \mathrm{~mm}$ ) coated with a layer of silicon spray.

About $20 \mathrm{~g}$ of the dried subsample was ground to a fine powder and sent to the Becquerel Laboratories at Lucas Heights in Australia for NAA. Using appropriate dose-rate conversion factors (Adamiec \& Aitken 1998) and beta attenuation factors (see Table 2 , note $\mathrm{d}$ ), the elemental concentrations were converted into external beta and gamma components, which were in turn attenuated for moisture content. These were summed together with a cosmic ray component (estimated using Prescott \& Hutton 1994) to give estimates of the total dose-rate for each sample.

Luminescence measurements were undertaken using a Daybreak 1100 automated system with an 1100FO/L combined fiber-optic/IRLED illuminator for optical stimulation (Bortolot 1997). Luminescence from the quartz grains was stimulated using a $150 \mathrm{~W}$ halogen lamp producing green light $(514 \Delta 34 \mathrm{~nm} ; \sim 20$ $\mathrm{mWcm}^{-2}$ ) defined by a basic excitation filter stack and an additional narrow band interference filter (Bortolot 1997). The quartz discs were screened for feldspar contamination using infrared stimulation from T-1 GaAlAs diodes $(880 \Delta 80 \mathrm{~nm}$; diode current $20 \mathrm{~mA})$. All OSL signals were detected with a photomultiplier tube characterized by $9 \mathrm{~mm}$ Schott UG11 ultraviolet detection filters. Daybreak TLApplic 4.26 software was used for hardware control and equivalent dose $\left(D_{e}\right)$ analysis.

$\mathrm{D}_{\mathrm{e}}$ measurements were determined using the singlealiquot regenerative-dose (SAR) protocol developed by Murray \& Wintle (2000). In the SAR method, each natural or regenerated OSL signal is corrected for changes in sensitivity using the OSL response to a subsequent test dose. The natural dose $(\mathrm{N})$ was measured in the first cycle, and thereafter five regeneration doses $\left(\mathrm{R}_{1}\right.$ to $\left.\mathrm{R}_{5}\right)$ were administered. The first three were used to bracket the natural luminescence level $\left(\mathrm{R}_{1}<\mathrm{N} \sim \mathrm{R}_{2}<\mathrm{R}_{3}\right)$; the fourth $\left(\mathrm{R}_{4}\right)$ was set at zero to monitor recuperation (i.e. $\mathrm{R}_{4} / \mathrm{N}$ ); and the fifth dose was made equal to the first to monitor reproducibility of the sensitivity correction (i.e. $\mathrm{R}_{5} / \mathrm{R}_{1}$ ). Each measurement cycle comprised a regeneration dose (zero for natural), a preheat of $200^{\circ} \mathrm{C}$ for $10 \mathrm{~s}$, optical stimulation for $100 \mathrm{~s}$ (sample temperature of $125^{\circ} \mathrm{C}$ ), a constant test-dose, a test-preheat cut after a linear temperature ramp to $160^{\circ} \mathrm{C}$ and a final optical stimulation for $100 \mathrm{~s}$ (at $125^{\circ} \mathrm{C}$ ). The net-natural and net-regenerated OSL were derived by integrating the OSL signal over the first 0 $1 \mathrm{~s}$, and subtracting a background integral from the final 90-100 s of stimulation; the net-test-dose response was derived by subtracting the background from the preceding natural and regenerative OSL signals.

Multiple $D_{e}$ estimates were carried out on the sample. Growth curves were plotted using the net-regenerated data divided by the subsequent response to the net-testdose. The growth curve data were fitted with a single saturating exponential function and the $\mathrm{D}_{e}$ was estimated by interpolation with the net-natural sensitivitycorrected luminescence level. Two rejection criteria were utilized; if recuperation was $>5 \%$ of the natural level and if the recycling ratio between repeat regenerative levels was $>10 \%$. If a disc failed to meet these criteria the result was discarded and a new disc measured. The distribution in $\mathrm{D}_{\mathrm{e}}$ results was analyzed using a histogram plot.

\section{Regional setting and glacial chronology}

The Qilian Shan is at the northeastern margin of the Tibetan Plateau and is believed to have uplifted along thrusts within a horsetail splay at the westernmost end of the Altyn Tagh Fault (Tapponnier et al. 1990). The peaks of the Lenglong Ling Mountains are around $4800 \mathrm{~m}$ a.s.l., the highest reaching $5255 \mathrm{~m}$ a.s.l. The contemporary snowline elevation is between 4400 and $4600 \mathrm{~m}$ a.s.l., and alpine permafrost exists throughout the range (Shi 1988; Rose et al. 1998). The mean annual temperature and precipitation at Menyuan is $0.6^{\circ} \mathrm{C}$ and $520 \mathrm{~mm}$, respectively (Rose et al. 1998). Nearly all the precipitation falls as snow and $84 \%$ of this occurs 


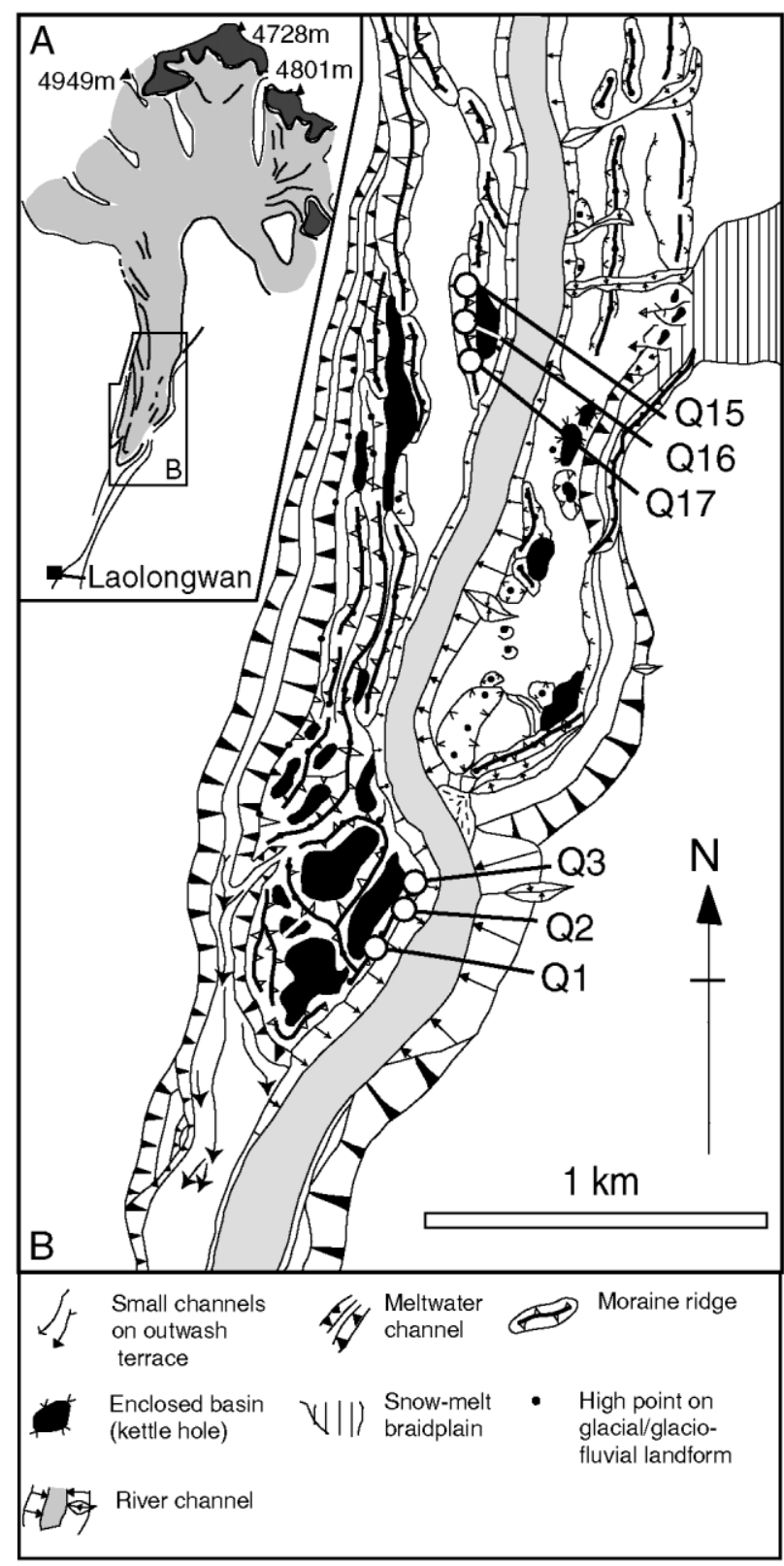

Fig. 5. Geomorphic map of Laolongwan Valley (adapted from Rose et al. 1998) showing the sites where samples were collected for CRN and OSL dating.

during the summer months (May-September; Rose et al. 1998). The main rock types are sandstones, conglomerates, shales, schists, phyllites, slates and agglomerates.

The glacial geology of this region was described by Li \& Li (1991), Shi (1992), Kang (1992), Guo \& Chen (1994), and Rose et al. (1998). On the basis of radiocarbon dating in the Gangshiga valley $(\mathrm{Li} \& \mathrm{Li}$ 1991; Kang 1992; Guo et al. 1995), terrace stratigraphy in the Laolongwan valley (Guo \& Chen 1994; Guo et al.
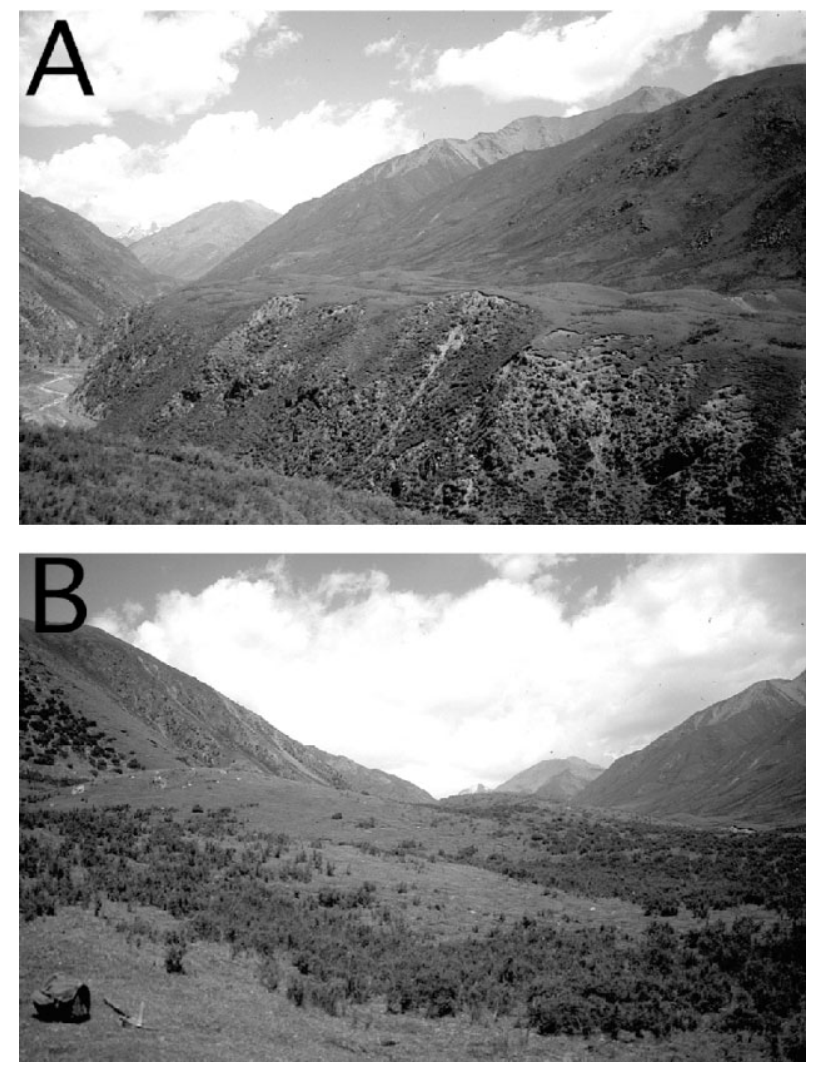

Fig. 6. Views of end moraine in the Laotugou Valley. A. View looking NE illustrating the hummocky surface of the end moraine. B. View of moraine where samples Q18, Q19 and Q20 were collected for CRN dating.

1995) and Schmidt Hammer readings at high elevations (Rose et al. 1998), the glacial landforms are believed to have formed during and since the Last Glacial Maximum (LGM). Zhou et al. (2002) presented radiocarbon, electron spin resonance (ESR) and thermoluminescence (TL) dates to constrain the timing of glaciation along the northern side of the range. They showed that glacial advances occurred during MIS 12, MIS 6, MISs 2-4, the Neoglacial and the Little Ice Age. They also referenced ESR, and radiocarbon dates on tills in the Gangshiga valley showed that a maximum advance may have occurred during the early part of the last glacial cycle (during MISs 2-4). However, they provided no details either on the methods used or on the exact sampling locations.

\section{Laolongwan valley}

The glacial landforms in the Laolongwan valley are described in detail in Rose et al. (1998). An impressive moraine complex exists beyond the mountain front comprising latero-frontal moraines that traverse the valley and hummocky moraines enclosing kettle holes at an altitude of $\sim 3200-3400 \mathrm{~m}$ a.s.1. (Fig. 5). Outwash 


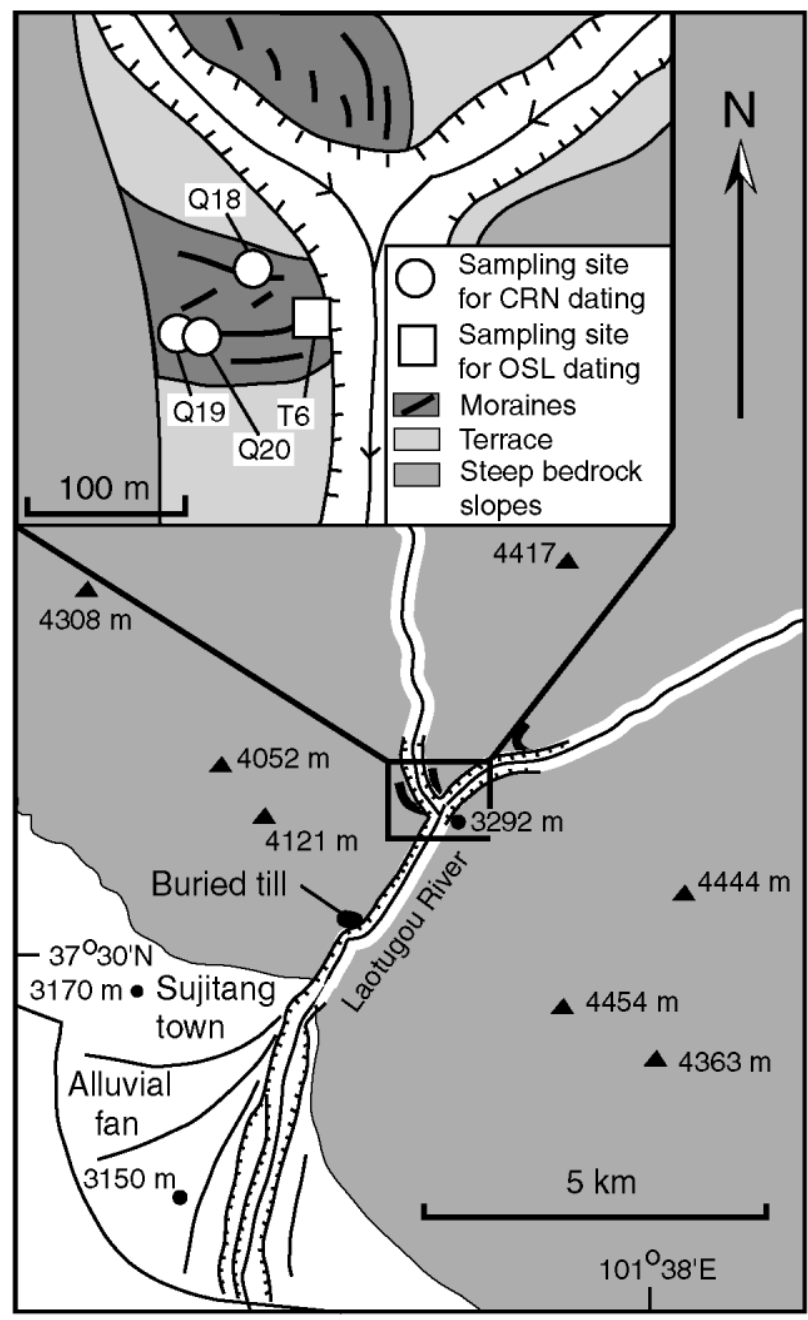

Fig. 7. Sketch map of the Laotugou valley showing the position of the moraines that were sampled for CRN and OSL dating.

fans and terraces exist beyond these terminal moraines. These terraces and fans, and some of the moraine ridges, are capped with pebbly and sandy silt that in places has been reworked by slope processes. Sampling for CRN dating concentrated on the moraine ridges within the terminal moraine complex.

\section{Laotugou valley}

The glacial geology of this valley has not been described previously. We identified a dissected lateroterminal moraine at an altitude of $\sim 3270 \mathrm{~m}$ a.s.l. that traverses the valley within the mountain range (Figs 6, 7). This moraine ridge is covered with a discontinuous $1 \mathrm{~m}$ thick deposit of pebbly silt and thick turf. Although surface boulders are sparse, sufficient boulders were sampled (Q18, Q19 and Q20) to ensure reliable CRN dating from the crest of the southernmost part of the latero-frontal moraine. A sample for OSL dating was

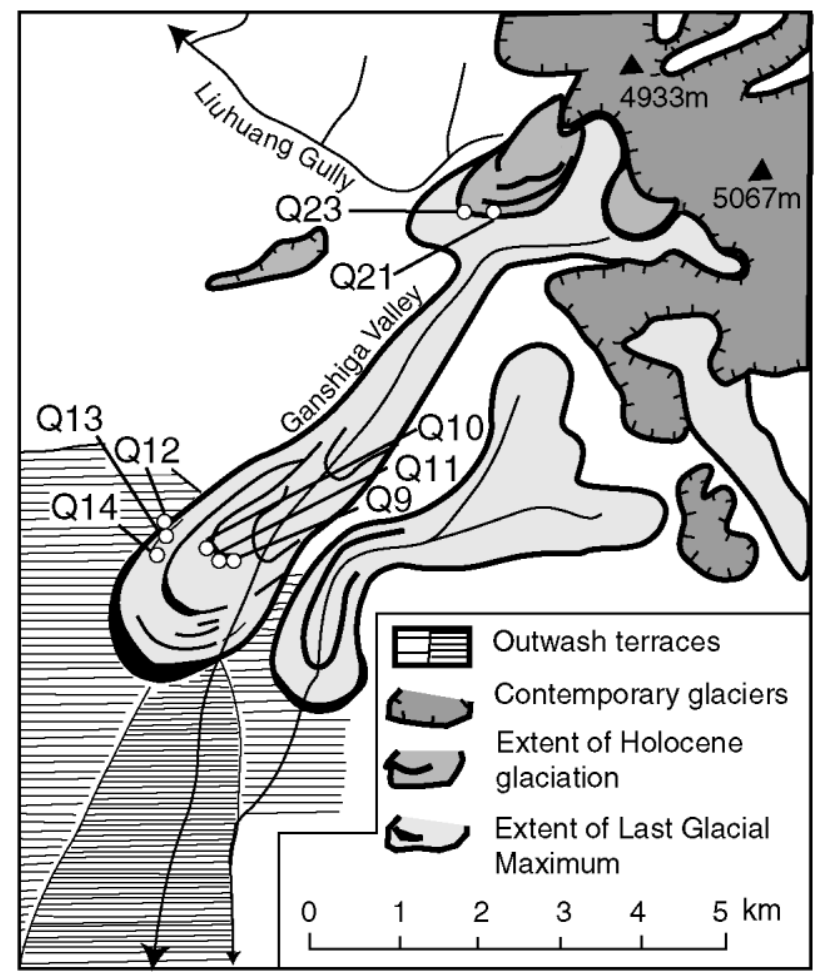

Fig. 8. Geomorphic map of Gangshiga Valley (adapted from Rose $e t$ al. 1998) showing the sites where samples were collected for CRN and OSL dating.

collected from the pebbly silt deposit. There is no geomorphic evidence to suggest that ice advanced beyond the mountain front in this valley. However, a massive matrix-supported diamict containing bulletshaped, edge rounded pebbles and cobbles, overlain by a $>2 \mathrm{~m}$ thick deposit of imbricated cobbles and pebbles is present $\sim 2-2.5 \mathrm{~km}$ down-valley from the laterofrontal moraine $\left(37^{\circ} 30.32^{\prime} \mathrm{N} / 101^{\circ} 34.88^{\prime} \mathrm{E}\right)$. This deposit may be till deposited during an earlier advance and then subsequently overlain by glaciofluvial outwash. However, it was not possible to date it.

\section{Gangshiga valley}

Rose et al. (1998) also described the glacial geology of this valley in great detail. Like the Laolongwan valley, impressive latero-frontal moraines are also present emerging from the mountain front at an altitude of $3300-3400 \mathrm{~m}$ a.s.l. (Fig. 8). A second set of laterofrontal moraines is present within $1-2 \mathrm{~km}$ of the contemporary glaciers at $\sim 4200 \mathrm{~m}$ a.s.l. Both sets of moraines were sampled for CRN dating (Fig. 8).

\section{Dating results}

The boulders that were dated using CRN methods on the 


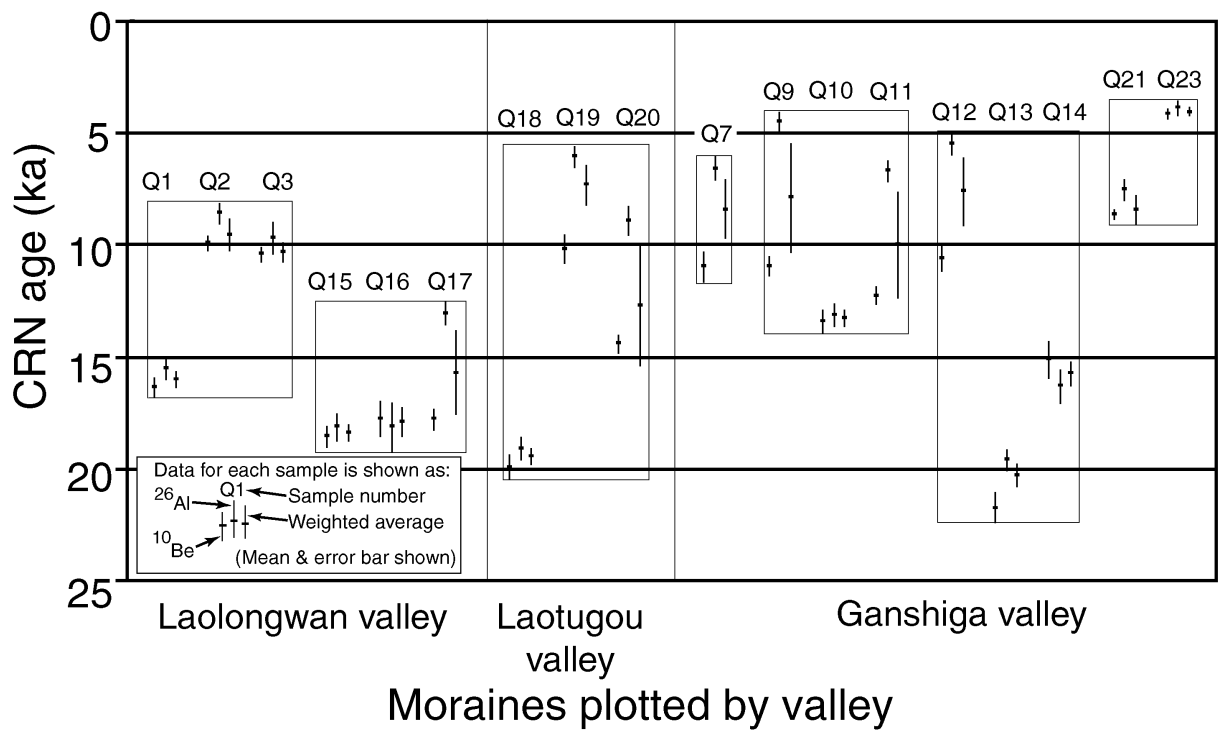

Fig. 9. CRN dates plotted by moraine ridge and relative ages. The boxes enclose individual moraines. latero-frontal moraines marking the maximum extent of ice in all three valleys range in age from the latter part of the LGM to the early Holocene (Fig. 9). There is a considerable degree of variance in ages on boulders that were dated from the same moraine ridge. CRN dates on boulders (Q12, Q13 and Q14) from the outermost moraine ridge in the Gangshiga Valley, for example, have ages of $\sim 8 \mathrm{ka}, \sim 20 \mathrm{ka}$ and $16 \mathrm{ka}$. Similarly in the Laotugou Valley, boulders Q18, Q19 and Q20 from the same moraine complex have ages of $\sim 20 \mathrm{ka}, \sim 7 \mathrm{ka}$ and $13 \mathrm{ka}$, respectively. The most consistent set of data is from a lateral moraine in the Laolongwan valley. Here boulders Q15, Q16 and Q17 all have ages of $~ 16-$ $18 \mathrm{ka}$, providing confidence that the moraine formed $\sim 16000-18000$ years ago. However, a moraine $\sim 1 \mathrm{~km}$ down-valley from the 16000-18000 year old moraine, and clearly morphostratigraphically older, has CRN ages from boulders Q1, Q2 and Q3 of $\sim 16 \mathrm{ka}, \sim 10 \mathrm{ka}$ and $\sim 10 \mathrm{ka}$, respectively.

The younger ages on the morphostratigraphically older moraine and the wide range of ages within sets of boulders collected from individual moraines throughout the region indicate that one or more of the fundamental assumptions used in obtaining ages is not valid at this field site. Cosmic radionuclide surface exposure ages usually assume no burial and no erosion. The maximum production of CRNs occurs in the top $5 \mathrm{~cm}$ of a rock surface and diminishes exponentially with depth. Our derived ages are based on the assumption of no shielding. If a boulder was initially buried, or shielded, by more than $10 \mathrm{~cm}$ within a moraine it would produce an apparent age that is markedly less than the true age of the moraine. This may explain the young CRN surface exposure ages for samples Q2, Q3 and Q19. All these have low boulder relief (Table 1) and may have been exhumed a significant time after they were deposited.

Alternatively, a fresh surface can be exposed to cosmic rays through disturbance or toppling of unstable boulders. This process is inherently stochastic and would produce seemingly random young ages. This may be the case for sample Q12, which has a very young age and is offset from the crest of the moraine. Deep weathering and exfoliation would also produce young apparent ages. All these factors, and others not detailed here, result in scatter and accordingly these are taken as minimum ages. Alternatively, older ages can be produced if boulders inherit CRNs from prior exposure. All these processes are stochastic and hence in an environment where weathering and erosional processes are dynamic it is likely that boulders on moraines will have very different histories and hence different ages. Collecting multiple boulders from individual moraine ridges and from morphostratigraphically similar moraines in adjacent valleys may make it possible to determine the age of landforms if the ages cluster.

We believe that in the Qilian Shan two main factors dominate potential variability in boulder ages. These are, first, severe weathering and, second, shielding due to the development of a thick organic turf and sporadic deposits of loess. We were particularly careful to sample only from boulders that did not show evidence of significant weathering or did not appear to have been recently exhumed from beneath the thick turf. However, both these processes may explain the younger ages.

The large spread of CRN ages on individual moraines and for morphostratigraphically similar moraines is not unusual in CRN surface exposure dating studies. Few studies provide large data sets of CRN surface exposures ages for moraines, but where a large data set has been produced the range of CRN surface exposure ages on an individual moraine and/or on morphostratigraphically similar moraines can be considerable. Some of the best data sets are provided by Gosse et al. (1995a, b) for the Wind River Mountains of 
Wyoming. The moraines that they dated are similar in age to the moraines in the Qilian Shan and therefore the Wind River Mountain data provide a good comparison. The spread of CRN surface exposure ages on individual moraines in the Wind River Mountains is similar to that for the Qilian Shan. For example, Gosse et al. (1995a) ${ }^{10} \mathrm{Be}$ CRN ages on terminal moraine boulders at Fremont Lake, which formed during the Last Pinedale Glacial, range in age from 14.4 to $21.7 \mathrm{ka}$ (16 dates). Gosse et al. (1995b) also measured $10{ }^{10} \mathrm{Be}$ exposure ages on the Titcomb Lake moraine. The age range was less varied, but still significant, varying from $\sim 10.4$ to $\sim 14.6 \mathrm{ka}$. The moraine was bracketed by CRN dates on younger and older landforms within and beyond the glacial limit, respectively. Given this and the clustering of ages around $13 \mathrm{ka}$, Gosse et al. (1995) were able to confidently assign the moraine to the Younger Dryas Stade.

Similarly, the work by Phillips et al. (1996) on the Late Pleistocene glacial chronologies in the Sierra Nevada illustrates the large spread of CRN surface exposure ages that are produced for individual moraines. In this study, CRN ${ }^{36} \mathrm{Cl}$ was used to date a succession of moraines in several valleys. The data for moraines that formed during the Tioga 3 Glacial provide another good comparison with our Qilian Shan data. Their CRN surface exposure ages for boulders on moraines in the Bishop Creek, Chiatovich Creek, Little McGee Creek and Bloody Canyon ranged from $6.9 \mathrm{ka}$ to $29.7 \mathrm{ka}$ (20 dates), $2.3 \mathrm{ka}$ to $22.5 \mathrm{ka}$ ( 21 dates), $11.7 \mathrm{ka}$ to $39.3 \mathrm{ka}$ (13 dates) and $4.3 \mathrm{ka}$ to $19.8 \mathrm{ka}$ (9 dates), respectively. Nevertheless, the clustering of ages and the bracketing by CRN dated younger and older moraines provided confidence that the age of Tioga 3 was $\sim 15-17 \mathrm{ka}$.

Briner et al. (2002) provide another example of the large spread of CRN ages on morphostratigraphically similar moraines. Using ${ }^{10} \mathrm{Be}$ and ${ }^{26} \mathrm{Al} \mathrm{CRNs,} \mathrm{they}$ dated 11 boulders on Lateglacial moraines in the Ahklun Mountains, southwestern Alaska. The CRN surface exposure ages ranged from $9.4 \mathrm{ka}$ to $16.2 \mathrm{ka}$. On the basis of the clustering of dates around $9.4 \mathrm{ka}$ and $11.7 \mathrm{ka}$, and radiocarbon dating, they suggested that the CRN surface exposure ages provided a minimum age on the moraine assigning it to the Younger Dryas Stade.

The spread of CRN ages on an individual moraine is also illustrated by Schäfer et al. (2001) in Litang County of SE Tibet. They provide CRN surface exposure dates for five boulders on one moraine that ranged in age from 13.3 to 17.9 ka. Furthermore, in the Himalaya, Phillips et al. (2000) presented $10 \mathrm{CRN}$ dates from morphostratigraphically similar, yet distantly spaced, moraines (2-3 boulders per moraine) that had a spread of ${ }^{10} \mathrm{Be}$ CRN surface exposure ages of $4.1 \mathrm{ka}$ to $19.2 \mathrm{ka}$. They suggested that the dates clustered around $8 \mathrm{ka}$ and attributed the moraines to an early to middle Holocene glacial advance that might correlate with the global temperature decrease at $\sim 8.5 \mathrm{ka}$ which resulted from the catastrophic drainage of the Laurentide lakes into the North Atlantic at $8.47 \mathrm{ka}$. Such correlations are obviously tentative, but in an area where no numerical dating has previously been undertaken they provide a first-order understanding of the glacial history that can be tested and/or refined in future studies.

From this and the above studies it is clear that moraines have a complex history that may include processes of erosion, mass movement, deposition and sourcing of boulders from different settings. This produces a wide range of CRN surface exposure ages for boulders on an individual moraine. Nevertheless, dating large numbers of boulders on individual moraines allows an assessment of the reliability of the dating and helps illustrate the dynamics of surface processes that affect glacial landforms.

The result for the single OSL sample (T6) extracted from the pebbly, silty deposit exposed in the lateroterminal moraine in the Laotugou valley is given in Table 2. Replicated single aliquot measurements demonstrate a tight distribution of $D_{e}$ values; the mean $\mathrm{D}_{\mathrm{e}}$ value being $42.42 \mathrm{~Gy}$ with a standard deviation of $1.18 \mathrm{~Gy}$. The adjusted standard error, after incorporating uncertainty in beta source calibration, is $\pm 2.17 \mathrm{~Gy}$ or $\pm 5 \%$, indicating that the $\mathrm{D}_{\mathrm{e}}$ is highly reproducible. Indeed, the error is dominated by the uncertainty in laboratory beta source dose-rate. The high reproducibility in $D_{e}$ values suggests that the loessic colluvium was sufficiently bleached by solar exposure prior to deposition on the moraine, giving us considerable confidence that the OSL age is accurate. The OSL date for the loessic colluvium sediment T6 capping the latero-terminal moraine in the Laotugou valley is $11.8 \pm 1.0 \mathrm{ka}$.

\section{Discussion}

On the basis of those CRN dates that do indicate clustering of ages, we conclude that the moraines along the southwestern slopes of the Qilian Shan formed during a period encompassing the latter part of the LGM to the Early Holocene. The CRN dates suggest that glaciers were advancing and filling the tributary valleys and flowing on to the forelands at $\sim 12-20 \mathrm{ka}$. On the basis of the lacustrine record in the Qaidam Basin, Hövermann \& Süssenberger (1986) demonstrated the likelihood that a Late Glacial advance occurred south of the Qaidam Basin around $15 \mathrm{ka}$. In addition, Schäfer et al. (2001) showed that glaciers advanced at $\sim 13-24 \mathrm{ka}$ in Litang County in SE Tibet. Furthermore, Owen et al. (2002c) showed that glaciers in the La Ji Mountains, $\sim 150 \mathrm{~km} \mathrm{SSW}$ of the Qilian Shan, were probably advancing at $\sim 15 \mathrm{ka}$. It is reasonable therefore to suggest that moraines dated in the Qilian Shan (this study) formed during the latter part of the LGM and may be broadly coincident with Heinrich Event 1 (H1) at $14.3{ }^{14} \mathrm{C}$ ka BP. The lack of resolution in our data for 
this region, however, requires that this correlation be labeled as suggestive, but not proven. Recent work indicates that glaciers and ice sheets in other regions of the world maintained their maximum extent until $\sim \mathrm{H} 1$, after which they underwent significant retreat (Licciardi et al. 2001; Dyke et al. 2002; Clague \& James 2002). Likewise, glaciers in other parts of Tibet and the Himalaya probably advanced and/or were maintained after the LGM until $\sim 15 \mathrm{ka}$ (Owen et al. 2001, 2002a, b, c). The OSL date of $11.8 \pm 1.0 \mathrm{ka}$ validates the CRN dates suggesting that glaciers had retreated significantly by the Younger Dryas Stade. Furthermore, the OSL date shows that loessic silts, making up a discontinuous $\sim 1 \mathrm{~m}$ thick deposit, were forming during, or shortly after, the Younger Dryas Stade, a situation that probably continues to this day.

Our data broadly agree with the relative dating work of Li \& Li (1991), Shi (1992), Guo \& Chen (1994) and Rose et al. (1998). Our conclusion that glaciers probably existed at their terminal positions until the Lateglacial, however, contrasts with Zhou et al.'s (2002) interpretation of the earlier radiocarbon dating and their electron spin resonance (ESR) dating, which they suggest shows that the tills within the Gangshiga valley may have formed earlier in the last glacial cycle (during MISs 2-4). The difference in the dating results and interpretation might be explained if the ESR and radiocarbon dates are dating tills that were originally deposited early in the last glacial cycle and were reworked by a later glacial advance to produce the landforms and boulders that we dated in our study. In this scenario the sediment may not have been adequately reset for ESR dating and organic material may have been derived. This would produce older dates than the true age of the landforms. Alternatively, the sediments that were dated by ESR methods might not have been adequately reset during their initial deposition. This would produce older ages and therefore the tills could have conceivably been deposited during the LGM and/or Lateglacial. Furthermore, care must be taken when evaluating the radiocarbon ages because the dating was undertaken on bulk samples using conventional radiocarbon methods and it is difficult to adequately evaluate whether there is the problem of incorporating different ages and sources of carbon. Furthermore, the absence of any CRN dates older than $20 \mathrm{ka}$ suggests that the ESR and radiocarbon methods are not recording the true age of the moraines that now form the prominent landforms in the valleys that we examined.

Constraining the timing of glaciation in this region is helpful in testing the synchroneity of glaciation across the Himalayan-Tibetan region. The new data set that is being produced suggests that glaciers throughout the Himalayan-Tibetan region were in a state of advance until at least $15 \mathrm{ka}$, albeit restricted in extent (Owen et al. 2001, 2002a, b, c). As more data become available throughout Central Asia, it may be possible to elucidate the relative roles of the south Asian summer monsoon and the mid-latitude westerlies in the glaciation of high Asia (cf. Benn \& Owen 1998).

\section{Conclusions}

Our CRN dates show that glaciers extended 5 to $10 \mathrm{~km}$ beyond their present positions during the global LGM and probably maintained their maximum extent until the Lateglacial. An OSL date of $11.8 \pm 1.0 \mathrm{ka}$ on silts that cap a latero-frontal moraine show that ice had retreated significantly by the end of the Pleistocene and that loess was beginning to form in this region in response to the changing climate during and after the Younger Dryas Stade. These data support the view that glaciers throughout Tibet and the Himalaya were probably maintained at or near their maximum LGM limit into the Lateglacial. This study also highlights the need for undertaking extensive programs of CRN numerical dating, which includes a large number of dates (several moraines of the same age with $\gg 3 \mathrm{CRN}$ surface exposure dates per moraine), to provide confidence in the reliability of the dating technique for defining the age of moraines in high mountain environments.

Acknowledgements. - We thank the National Geographic Society for funding our fieldwork. This work was performed under the auspices of the U.S. Department of Energy by the University of California, Lawrence Livermore National Laboratory under Contract No. W7405-Eng-48 as part of an IGPP/LLNL research grant. We thank Frank Lehmkuhl, Jan Piotrowski and an anonymous reviewer for their constructive and positive comments on our paper.

\section{References}

Adamiec, G. \& Aitken, M. 1998: Dose-rate conversion factors: update. Ancient TL 16, 37-50.

Aitken, M. J. 1998: An Introduction to Optical Dating, 267 pp. Oxford University Press, Oxford.

Benn, D. \& Owen, L. A. 1998: The role of the Indian summer monsoon and the mid-latitude westerlies in Himalayan glaciation: review and speculative discussion. Journal of the Geological Society 155, 353-363.

Bortolot, V. J. 1997: Improved OSL excitation with fiberoptics and focused lamps. Radiation Measurements 27, 101-106.

Briner, J. P., Kaufman, D. S., Werner, A., Caffee, M., Levy, L., Manley, W. F., Kaplan, M. R. \& Finkel, R. C. 2002: Glacier readvance during the late glacial (Younger Dryas?) in the Ahklun Mountains, southwestern Alaska. Geology 30, 679-682.

Bush, A. B. G. 2000: A positive climatic feedback mechanism for Himalayan glaciation. Quaternary International 65/66, 3-13.

Clague, J. J. \& James, T. S. 2002: History and isostatic effects of the last ice sheet in southern British Columbia. Quaternary Science Reviews 21, 71-87.

Derbyshire, E., Shi, Y. F., Li, J. J., Zheng, B. X., Li, S. J. \& Wang, J. T. 1991: Quaternary glaciation of Tibet: the geological evidence. Quaternary Science Reviews 10, 485-510.

Dey, B. \& Bhanu Kumar, O. S. R. U. 1982: An apparent relationship between Eurasian spring snow cover and the advance period of the 
Indian summer monsoon. Journal of Applied Meteorology 21, 1929-1923.

Dickson, R. R. 1984: Eurasian snow cover versus Indian monsoon rainfall: an extension of the Hahn-Shukla results. Journal of Climatology and Applied Meteorology 23, 171-173.

Dyke, A. S., Andrews, J. T., Clark, P. U., England, J., Miller, G. H., Shaw, J. \& Veillette, J. J. 2002: The Laurentide and Innuitian ice sheets during the Last Glacial Maximum. Quaternary Science Reviews 21, 9-31.

Gosse, J. C., Evenson, E. B., Klein, J., Lawn, B. \& Middleton, R. 1995b: Precise cosmogenic ${ }^{10} \mathrm{Be}$ measurements in western North America: support for a global younger Dryas cooling event. Geology 23, 877-880.

Gosse, J. C., Klein, J., Evenson, E. B., Lawn, B. \& Middleton, R. 1995a: Beryllium-10 dating of the duration and retreat of the Last Pinedale glacial sequence Science 268, 1329-1333.

Grün, R. 1991: Age.exe. Computer program, RSES, Canberra.

Guo, H. \& Chen, Y. 1994: Study on glacial sequences, loess records and terrace series of the southern foot of Lenglongling. Abstracts of International Symposium and Field Workshop on Glacial Deposits and Environment in Monsoon Asia. Lanzhou University, 20-30 July, 1994, Lanzhou University, China, 42-43.

Guo, H., Chen, Y. \& Li, J. 1995: A preliminary study on glacial sequences, loess record and terraces in the south piedmont of Lenglongling, Qilian Shan. Journal of Lanzhou University (Natural Version) 31, 102-110.

Hahn, D. G. \& Shukla, J. 1976: An apparent relationship between Eurasian snow cover and Indian monsoon rainfall Journal of Atmospheric Science 33, 2461-2462.

Hövermann, J. \& Süssenberger, H. 1986: Zur Klimageschichte Hoch- und Ostasiens. Berliner Geographische Studien 20, 173186.

Kang, J. 1992: Quaternary glacial evolution sequence in the south slope of Lenglongling of Qilian Mountains Glaciology and Geocryology 14, 352-355.

Kohl, C. P. \& Nishiizumi, K. 1992: Chemical isolation of quartz for measurement of in-situ-produced cosmogenic nuclides Geochimica et Cosmochimica Acta 56, 3583-3587.

Lal, D. 1991: Cosmic ray labeling of erosion surfaces: in situ nuclide production rates and erosion models Earth and Planetary Science Letters 104, 429-439.

Lal, D. \& Peters, B. 1967: Cosmic ray produced radioactivity on the Earth. In Flugge, S. (ed.): Handbuch der Physik, 551-612. Springer-Verlag.

Lehmkuhl, F. 1997: Late Pleistocene, Late-Glacial and Holocene glacier advances on the Tibetan Plateau. Quaternary International 38/39, 77-83.

Lehmkuhl, F., Owen, L. A. \& Derbyshire, E. 1998: Late Quaternary glacial history of Northeastern Tibet. Quaternary Proceedings 6 , 121-142.

Li, B. \& Li, J. 1991: Quaternary Glacial Distribution Map of the Qinghai-Xizang (Tibet) Plateau, 10 pp. Science Press, Beijing.

Licciardi, J. M., Clark, P. U., Brook, E. J., Pierce, K. L., Kurz, M. D., Elmore, D. \& Sharma, P. 2001: Cosmogenic 3He and 10Be chronologies of the late Pinedale northern Yellowstone ice cap, Montana, USA Geology 29, 1095-1098.

Murray, A. S. \& Wintle, A. G. 2000: Luminescence dating of quartz using an improved single-aliquot regenerative-dose protocol. Radiation Measurements 32, 57-73.
Mejdahl, V. 1979: Thermoluminescence dating: beta-dose attenuation in quartz grains. Archaeometry 21, 61-72.

Nishiizumi, K., Winterer, E. L., Kohl, C. P., Klein, J., Middleton, R., Lal, D. \& Arnold, J. R. 1989: Cosmic ray production of ${ }^{10} \mathrm{Be}$ and ${ }^{26} \mathrm{Al}$ in quartz from glacially polished rocks. Journal of Geophysical Research 94, 17907-17915.

Owen, L. A., Gualtieri, L., Finkel, R. C., Caffee, M. W., Benn, D. I. \& Sharma, M. C. 2001: Cosmogenic radionuclide dating of glacial landforms in the Lahul Himalaya, Northern India: defining the timing of Late Quaternary glaciation. Journal of Quaternary Science 16, 555-563.

Owen, L. A., Finkel, R. C., Caffee, M. W. \& Gualtieri, L. 2002a: Timing of multiple glaciations during the Late Quaternary in the Hunza Valley, Karakoram Mountains, Northern Pakistan: defined by cosmogenic radionuclide dating of moraines. Geological Society of America Bulletin 114, 593-604.

Owen, L. A., Finkel, R. C. \& Caffee, M. W. 2002b: A note on the extent of glaciation in the Himalaya during the global Last Glacial Maximum. Quaternary Science Reviews 21, 147-158.

Owen, L. A., Ma, H., Derbyshire, E., Spencer, J. Q., Barnard, P. L., Zeng, Y. N., Finkel, R. C. \& Caffee, M. W. 2002c: The timing and style of Late Quaternary glaciation in the La Ji Mountains, NE Tibet: evidence for restricted glaciation during the latter part of the Last Glacial. Zeitschrift für Geomorphologie (in press).

Phillips, W. M., Sloan, V. F., Shroder, J. F. Jr., Sharma, P., Clarke, M. L. \& Rendell, H. M. 2000: Asynchronous glaciation at Nanga Parbat, northwestern Himalaya Mountains, Pakistan. Geology 28, 431-434.

Phillips, F. M., Zreda, M. G., Benson, L. V., Plummer, M. A., Elmore, D. \& Sharma, P. 1996: Chronology for fluctuations in Late Pleistocene Sierra Nevada Glaciers and Lakes. Science 274, 749-751.

Prescott, J. R. \& Hutton, J. T. 1994: Cosmic ray contributions to dose rates for luminescence and ESR dating: large depths and long-term time variations. Radiation Measurements 23, 497-500.

Rose, J., Derbyshire, E., Guo, H. \& Ma, H. 1998: Glaciation in the Eastern Qilian Shan, Northwest China. Quaternary Proceedings 6, 143-152.

Rutter, N. W. 1995: Problematic ice sheets. Quaternary International 28, 19-37.

Schäfer, J. M., Tschudi, S., Zhao, Z., Wu, X., Ivy-Ochs, S., Wieler, R., Baur, H., Kubik, P. W. \& Schluchter, C. 2001: The limited influence of glaciations in Tibet on global climate over the past 170000 yr. Earth and Planetary Science Letters 6069, 1-11.

Shi, Y. 1988: Map of Snow, Ice and Frozen Ground in China Compiled by Lanzhou Institute of Glaciology and Geocryology, 32 pp. and map. China Cartographic Publishing House, Beijing.

Shi, Y. 1992: Glaciers and glacial geomorphology in China. Zeitschrift für Geomorphologie N.F. Suppl. Bd 86, 51-63.

Tapponnier, P., Meyer, B., Avouac, J. P., Peltzer, G., Gaudemer, Y., Gau, S., Xiang, H., Yin, K., Chen, Z., Cai, S. \& Dai, H. 1990: Active thrusting and folding in the Qilian Shan, and decoupling between the upper crust and mantle in northeastern Tibet. Earth Planetary Science Letters 97, 382-403.

Zhou, S., Li, J. \& Zhang, S. 2002: Quaternary glaciation of the Bailang Valley, Qilian Shan. Quaternary International 97/98, 103-110. 